\title{
Histochemical Study of Early Embryo Implantation in Rats
}

\author{
Estudio Histoquímico de la Implantación Temprana en Ratas
}

\author{
"Danilo Rodrigues Spósito \& **Arnaldo Rodrigues Santos Jr.
}

\begin{abstract}
SPÓSITO, D. R. \& SANTOS, A. R. Jr. Histochemical study of early embryo implantation in rats. Int. J. Morphol., 29(1):187-192, 2011.

SUMMARY: Embryo implantation is the process that results in attachment of the conceptus to the uterine wall. In this histochemical study, we investigated the early stage of embryo implantation in rats by morphological analysis and by the detection of total proteins and glycosaminoglycans using hematoxylin-eosin, toluidine blue at pH 4.0 (TB), and Xylidine Ponceau at pH 2.5 (XP). In non-pregnant females, the uterine layers could be clearly distinguished and showed the normal histology of the organ. In pregnant females, an increase in the number of cells and a reduction in the interstitial space were observed in the endometrium close to the implantation sites. The blastocyst was partially inserted in the endometrium, with the observation of the inner cells mass around the blastocyst cavity surrounded by trophoblastic cells. TB staining revealed mild metachromatic basophilia, which was more evident in the endometrial stroma around the implantation site. Histochemical staining with XP was also more intense in the stroma close to the site of implantation. On the other hand, histochemical staining with either TB or XP was more discrete at sites distant from the conceptus. This study demonstrated changes in the endometrial stroma in areas adjacent to the site of embryo implantation, with variations in glycosaminoglycans and proteins as demonstrated by the detection of anionic and cationic radicals, respectively.
\end{abstract}

KEY WORDS: Implantation window; Endometrium; Trophoblast; Embryo.

\section{INTRODUCTION}

Embryo implantation is the process that results in attachment of the conceptus to the uterine wall. The embryo is able to attach to different sites and surfaces of the maternal organism, whereas the endometrium seems to be more selective, permitting embryo implantation only within a short period of time, called the implantation window (Norwitz et $a l ., 2001)$. In rats and mice, the implantation window corresponds to a period of approximately $24 \mathrm{~h}$ between day 4 and day 5 of pregnancy. During this phase, the endometrium undergoes morphofunctional modifications induced by estrogen and progesterone that facilitate apposition, attachment and embryo invasion. The molecular basis of this phenomenon is still unclear, but it is known to involve changes in the glycocalyx of luminal epithelial cells and the expression of growth factors, in addition to adhesion molecules and glycosaminoglycans in the blastocyst and endometrial stroma, respectively (Castro-Rendón et al., 2006).

The implantation window also involves apposition and adhesion of the embryo to the endometrium and the emergence of cellular prolongations and culminates in the invasion of the embryo into the endometrial stroma. This process is mediated by a wide variety of molecules. This molecular dialog that occurs during implantation of the conceptus in the endometrium is characterized by cell-cell and cell-extracellular matrix interactions, with the participation of lectins, integrins, extracellular matrix metalloproteases and their inhibitors, and prostaglandins, in addition to growth factors, cytokines, angiogenic peptides and their receptors, and modulatory proteins (Staun-Ram \& Shalev, 2005; Castro-Rendón et al.; Alberts et al., 2008). If appropriately expressed or inhibited, each of these factors contributes to the uterine response, permitting or not embryo implantation. The morphofunctional characteristics of the endometrium during implantation are determinant for the success of this event.

Although the initial interaction between the conceptus and uterus is a complex phenomenon, studies investigating uterine morphology at the time of implantation are rare. We

\footnotetext{
* Instituto de Ciências Biológicas, Unipinhal. Espírito Santo do Pinhal, SP - Brasil.

* Centro de Ciências Naturais e Humanas, Universidade Federal do ABC, Santo André, SP - Brasil.
} 
therefore performed a histochemical study of this subject. The specific objectives were to morphologically evaluate the process of implantation in rats and to histochemically detect proteins and glycosaminoglycans.

\section{MATERIAL AND METHOD}

Animals: Non-pregnant Wistar rats in the phase of proestrus and pregnant rats in the early stage of embryo implantation were used. The study was approved by the Ethics Committee on Animal Experimentation of Centro Regional Universitário do Espírito Santo do Pinhal (Unipinhal) (CEPex protocol 040/07-CPE-PE 0.65). During the experiment, the animals received food and water ad libitum and were maintained at room temperature of approximately $25^{\circ} \mathrm{C}$ under adequate ventilation. After the contact with males, the females were removed on day 8 after the confirmation of pregnancy. The animals were anesthetized and sacrificed by pneumothorax. The animals were autopsied and the uterus was removed for histological and histochemical analysis.

Histological and histochemical analysis: Routine histological techniques were used. The material was rapidly fixed in $10 \%$ buffered formalin, $\mathrm{pH}$ 7.4. After washing under running water, the samples were dehydrated in an increasing alcohol series, cleared in xylene, embedded in paraffin, and cut into $5-\mu \mathrm{m}$ thick sections. The sections were stained with hematoxylin-eosin (HE) for general morphological analysis, with Xylidine Ponceau (XP) at pH 2.5 for the identification of cationic radicals, and with toluidine blue (TB) at $\mathrm{pH} 4.0$ for the identification of anionic radicals.

\section{RESULTS}

In non-pregnant females, HE staining permitted the clear distinction between the three uterine layers (endometrium, myometrium and perimetrium). These layers showed the normal histology of the organ (Fig. 1A and 1B). TB staining revealed discrete metachromatic basophilia in the endometrial epithelium and myometrium. Mild orthochromatic basophilia was observed in the other regions (Fig. 1C and 1D). Staining with XP showed more intense acidophilia in the myometrium and endometrial epithelium as expected. The endometrial stroma and perimetrium were mildly acidophilic (Fig. 1E and 1F).

In pregnant females, $\mathrm{HE}$ staining revealed an increase in the number of cells and a reduction in the interstitial space in endometrial regions close to the sites of implantation (Fig.
2A and 2B). These regions also contained cells with different morphology and histochemical properties, probably corresponding to modified endometrial cells due to the distance from the blastocyst (Fig. 2C and 2D). HE staining also identified the region where the blastocyst was partially inserted in the endometrium (Fig. 2B), with the observation of the inner cell mass around the blastocyst cavity surrounded by trophoblastic cells.

Also in pregnant females, staining with TB showed mild metachromatic basophilia, which was more evident in the endometrial stroma around the site of embryo implantation (Fig. 2E and 2F). XP staining also revealed more intense cytochemical staining in the stroma close to the site of implantation (Fig. 2G, 2H and 2I). On the other hand, histochemical staining with either TB or XP was more discrete at sites distant from the conceptus.

\section{DISCUSSION}

Histochemistry permitted the observation of marked basophilia in the endometrial stroma close to the sites of implantation. This basophilia was demonstrated by staining with TB, a basic dye that forms electrostatic bonds with acid radicals present in tissues. TB binds to $\mathrm{PO} 4-, \mathrm{SO} 4-$, and COO- groups that are found in DNA, RNA and glycosaminoglycans at pH 4.0 (Lison, 1960; Mello, 1997; Módis, 1991). Highly basophilic cytoplasm normally indicates a large amount of rRNA (Toboga \& Vilamaior, 2007; Pinto et al., 2007). On the other hand, stromal staining is related to alterations in the content of glycosaminoglycans and/or proteoglycans in the interstitial space (Haas et al., 2001; Santos et al., 2003; Martelli et al., 2007; Toboga \& Vilamaior). Stromal alterations in these regions as a consequence of extracellular matrix lysis by embryonic enzymes and the secretion of new components into the stroma may explain the changes observed.

Sulfated glycosaminoglycans are found in the endometrium at different proportions and during different phases of the estrous cycle (Gomes et al., 2007). The role of these glycosaminoglycans in the early stages of embryo implantation and/or development is uncertain. The present results indicate that the concentration of glycosaminoglycans is higher around the embryo. The results permit no conclusion whether glycosaminoglycans are produced by the embryo or by the endometrial cells themselves, but support the hypothesis that these components are important for early embryo development and/or the interaction of the embryo with the uterine stroma. Histochemical staining for glycosaminoglycans was less intense in the other regions. 

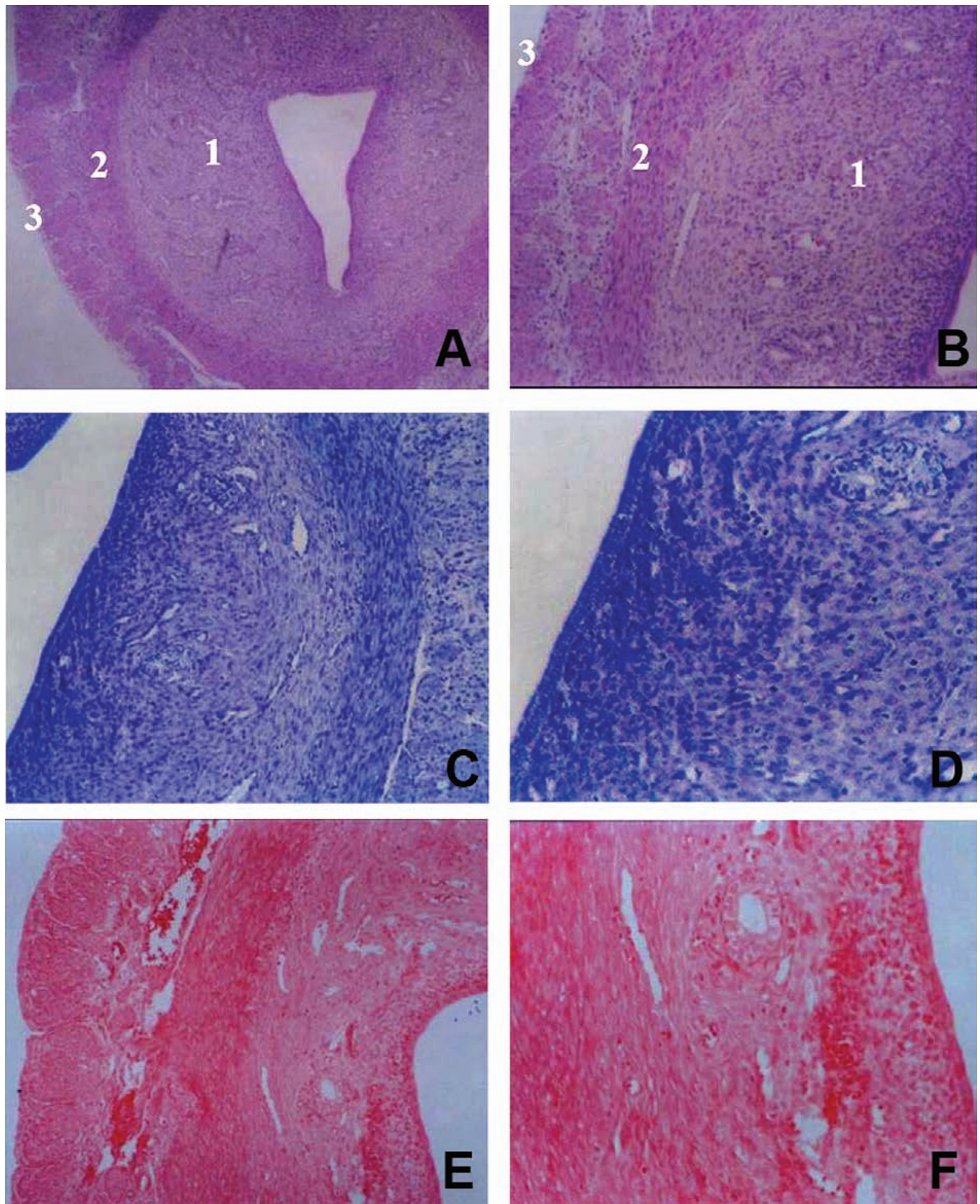

Fig. 1. (A) and (B) Control proliferative endometrium stained with hematoxylin-eosin. $1=$ endometrium, $2=$ myometrium, and 3 = perimetrium. (C) and (D) Control endometrium stained with toluidine blue. General view of the uterine endometrium, with the presence of more basophilic cells on the surface of the endometrium (close to the lumen). (E) and (F) Control endometrium stained with Xylidine Ponceau. Note in the endometrium the regions of higher acidophilia in the lining epithelium and vessels. The myometrium was also highly acidophilic. A, C and E: 100X final magnification; B, D and F: 400X final magnification. 

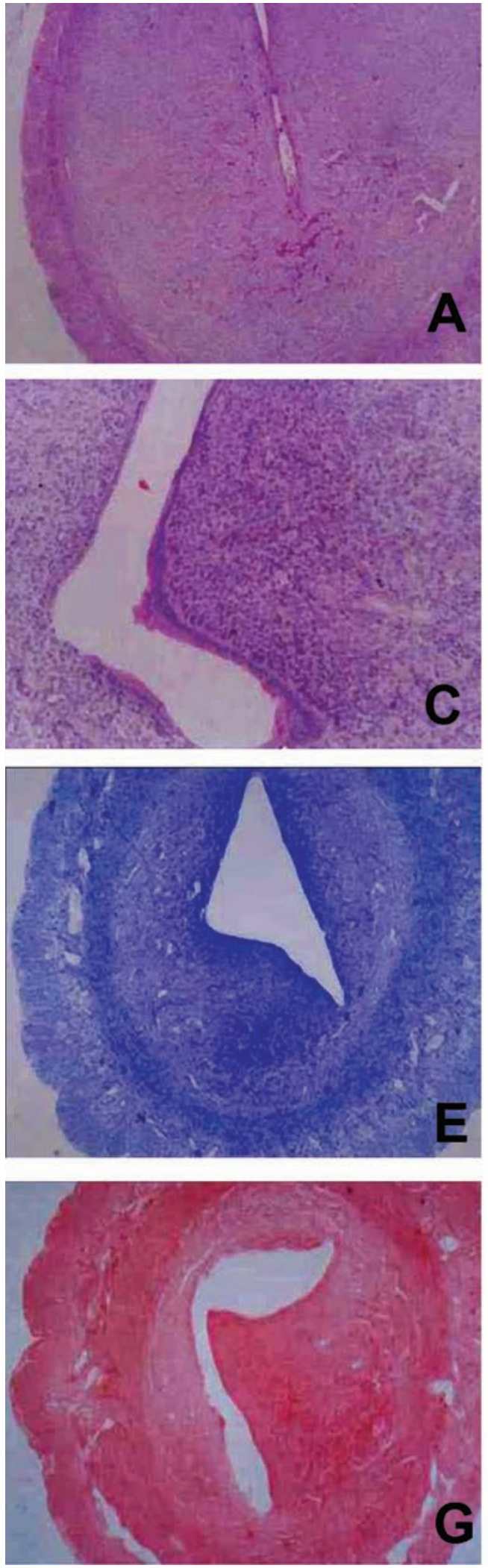
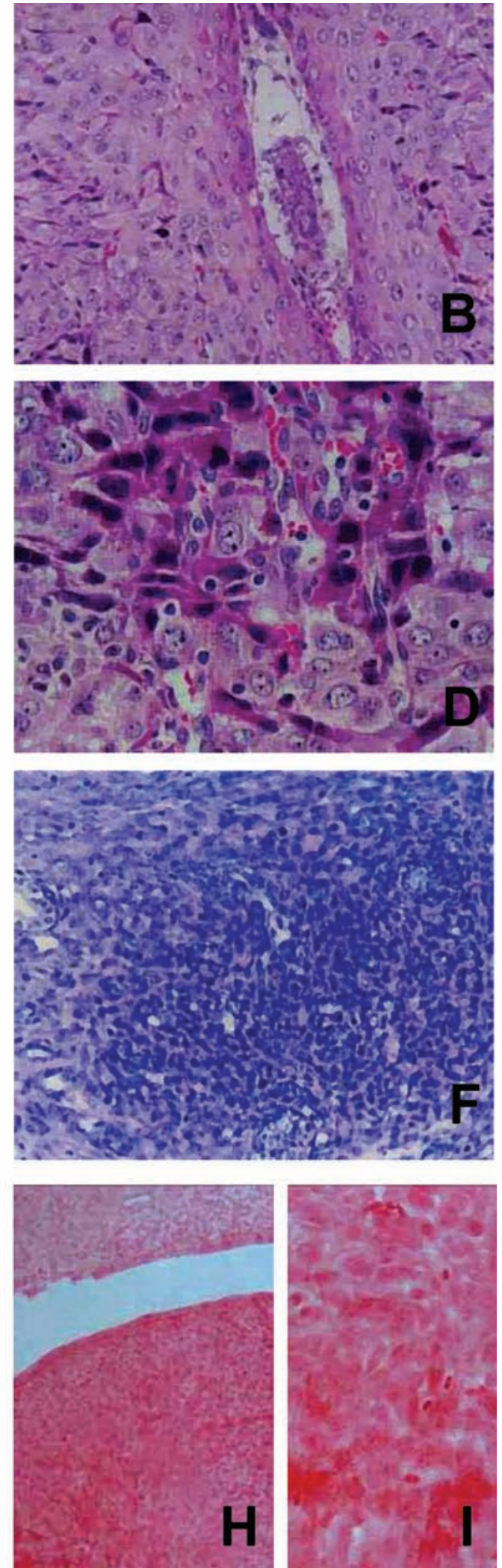

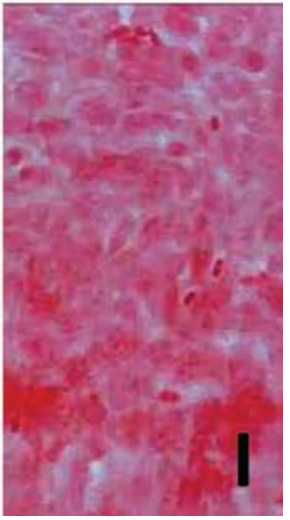

Fig. 2. Region of embryo implantation. A-D, Hematoxylin-eos in staining: (A) Region of the endometrium surrounding the embryo. Note the increase in the number of cells close to the site of embryo implantation. (B) Endometrial cells in contact with the embryo that undergo modifications probably induced by the embryo. Note the inner cell mass surrounded by the blastocyst cavity. (C) Panoramic view of the implantedembryo. (D) Detail of the previous figure showing the blastocyst. Also observe the trophoblast in contact with the endometrium. Note the presence of cells of different sizes, as well as intensely stained cells. $\mathrm{E}$ and $\mathrm{F}$, Toluidine blue staining: (E) Note the basophilic regions close to the implantation site. Observe the region of higher cell accumulation with higher basophilia in the stroma than regions more distant from the embryo. (F) Higher magnification of the implantation site. Note the cells showing mildly metachromatic basophilia. G-I, Xylidine Ponceau staining: (G) Note the more acidophilic regions close to the implantation site. (H) Higher magnification of the previous figure. Note the larger number of highly acidophilic cells. (I) Detail of highly acidophilic cells. A, C, E and $\mathrm{G}$ : $100 \mathrm{X}$ final magnification; B, D, F, H and I: 400X final magnification. 
In the uterus of pregnant females, small leucine-rich proteoglycans (SLRPs) such as decorin, lumican, biglycan, and fibromodulin are drastically remodeled within a few hours after fertilization, suggesting that ovarian hormone levels modulate their synthesis and degradation. In the study of Salgado et al. (2009a), all molecules except for fibromodulin showed a marked modulation in their distribution in the endometrial stroma according to estrogen levels. Differences in the distribution of SLRPs were observed between the superficial and deep layers of the endometrial stroma.

The expression of the proteoglycan versican has been evaluated during different phases of the estrous cycle in the uterus of normal and ovariectomized mice and ovariectomized mice submitted to hormone replacement therapy. Versican was exclusively expressed in the endometrial stroma during diestrus and proestrus. During estrus and metestrus, expression of versican was observed in both endometrial stroma and myometrium. Versican was not detected in the uterus of ovariectomized females. These results show that the expression of versican in the uterus is modulated by ovarian steroid hormones (Salgado et al., 2009b). Hyaluronic acid and versican have also been detected in the endometrial stroma during the preimplantation period. After implantation, hyaluronic acid disappears from the decidual region in the immediate vicinity of the implantation chamber, whereas versican accumulates in this region, suggesting that these proteoglycans play an important role in the proliferation and differentiation of endometrial fibroblasts into decidual cells, influencing trophoblast invasion (San Martin et al., 2003).

$\mathrm{XP}$ is an acidophilic dye that detects cationic $\mathrm{NH} 3+$ radicals, which are found in total proteins at $\mathrm{pH} 2.5$ (Lison; Mello; Módis; Martelli et al.; Pinto et al.; Toboga \& Vilamaior). The endometrial stroma is not a fibrous tissue and should therefore not show marked acidophilia. However, we observed more intense acidophilia in endometrial tissue close to the sites of implantation, a finding characterizing the deposition of large amounts of proteins at this site.
Morphological analysis by HE staining showed a large number of cells in the endometrium at these sites. It is possible that the proteins deposited are involved in the interaction between the embryo and endometrium. In addition, the trophoblastic cells detected showed even more intense cytoplasmic acidophilia than the endometrium itself, indicating that trophoblastic cells are high producers of these protein components.

During early pregnancy, local signaling of blastocysts further modifies the uterine environment and induces the secretion of specific proteins by the uterine epithelium (Butler, 2000), as well as extracellular matrix metalloproteases (StaunRam \& Shalev). Culture systems that permit to simulate the complex interactions between the embryo and endometrium will probably contribute to a better understanding of these interactions. The use of cells in culture to support in vitro embryo development is one of the strategies employed in embryo production laboratories. However, co-culture of embryos with trophoblastic cells or other types of feeder layers has shown that factors present in these culture systems favor early embryo development (Huang et al., 1997; Castro-Rendón et al., 2006).

Embryo implantation is a complex process that involves a series of biochemical and immunological mechanisms of the conceptus itself and of the mother. The uterine microenvironment plays a definitive function in the process of implantation. Thus, monitoring the uterine microenvironment during early pregnancy permits the characterization of events related to maternal-fetal activities to gain a better understanding of these biochemical events. Protein factors and/or glycosaminoglycans are involved in the interaction between the embryo and uterine endometrium. The present histochemical study demonstrated changes in the endometrial stroma in areas adjacent to the site of embryo implantation, with variations in glycosaminoglycans and proteins as demonstrated by the detection of anionic and cationic radicals, respectively.

SPÓSITO, D. R. \& SANTOS, A. R. Jr. Estudio histoquímico de la implantación temprana en ratas. Int. J. Morphol., 29(1):187-192, 2011.

RESUMEN: La implantación embrionaria es el proceso que resulta en la unión del embrión a la pared uterina. En este estudio histoquímico, se determinó la fase inicial de implantación del embrión en ratas mediante el análisis morfológico y por la detección de proteínas totales y glicosaminoglicanos con hematoxilina-eosina, azul de toluidina a pH 4,0 (TB) y xilidina Ponceau a un pH de 2,5 (XP). En las hembras no preñadadas, las capas del útero pueden ser claramente distinguidas y mostraron la histología normal del órgano. En las hembras preñadas, se observa un incremento en el número de células y una reducción en el espacio intersticial del endometrio para cerrar los sitios de implantación. El blastocisto se implanta parcialmente en el endometrio, con presencia de masa de células internas en torno a la cavidad del blastocisto, rodeado por las células trofoblásticas. La tinción TB reveló leve basofilia metacromática, lo cual fue más evidente en el estroma endometrial alrededor del sitio de implantación. Tinción histoquímica con XP también fue más intensa próximo del estroma en el sitio de implantación. Por otro lado, la tinción histoquímica, ya sea con la tuberculosis o XP fue más leve en los lugares distantes del embrión. Este estudio demostró cambios en el estroma del endometrio en las zonas adyacentes al sitio de la implantación del embrión, con variaciones en glucosaminoglicanos y proteínas, como lo demuestra la detección de radicales aniónicos y catiónicos, respectivamente.

PALABRAS CLAVE: Ventana de Implantación; Endometrio; Trofoblasto; Embrión. 


\section{REFERENCES}

Alberts, B.; Johnson, A.; Lewis, J.; Raff, M.; Roberts, K. $\&$ Walter, P. Molecular Biology of the Cell. $5^{\text {th }}$ ed. New York, Garland Science, 2008.

Butler, W. R. Nutritional interactions with reproductive performance in dairy cattle. Anim. Reprod. Sci., 2(60-61): 449-57, 2000.

Castro-Rendón, W. A.; Castro-Alvarez, J. F.; GuzmánMartinez, C. \& Bueno-Sanchez, J. C. Blastocystendometrium interaction: intertwining a cytokine network. Braz. J. Med. Biol. Res., 39(11): 1373-85, 2006.

Gomes, R. C. T.; Simões, R. S.; Soares, J. M. Jr.; Nader, H. B.; Simões, M. J. \& Baracat, E. C. Perfil de glicosaminoglicanos sulfatados no útero de camundongas durante o ciclo estral. Rev. Assoc. Med. Bras., 53(3):43-9, 2007.

Haas, V. R.; Santos, A. R. Jr. \& Wada, M. L. Behaviour of fibroblastic cells cultured in collagen I using the sandwich technique. Cytobios, 106(Suppl. 2):255-67, 2001.

Huang, H. Y.; Krüssel, J. S.; Wen, Y. \& Polan, M. Use of reverse transcription-polymerase chain reaction to detect embryonic interleukin-1 system messenger RNA in individual preimplantation mouse embryos cocultured with Vero cells. Human Reprod., 12(7):153744, 1997.

Lison, L. Histochimie et cytochimie animales. Principes et méthodes. $3^{\text {a }}$ ed. Paris, Gaulthier-Villars, 1960.

Martelli, A.; Santos, A. R. Jr. \& Jones A. R. Aspectos histológicos e histoquímicos de osteossarcomas em cães. Estud. Biol., 29:179-89, 2007.

Mello, M. L. S. Cytochemistry of DNA, RNA and nuclear proteins. Braz. J. Genet., 20(1):257-64, 1997.

Módis, L. Organization of the Extracellular Matrix: A Polarization Microscopic Approach. Boca Raton, CRC Press, 1991.

Norwitz, E. R.; Schust, D. J. \& Fisher, S. J. Implantation and the survival of early pregnancy. N. Engl. J. Med., 345:1400-8, 2001.

Pinto, J. P.; Teixeira, L. B. C. \& Santos, A. R. Jr. Estudo histopatológico e histoquímico de mastocitomas na região de Espírito Santo do Pinhal. Rev. Acad. Cien. Agr. Amb., 5(3):265-76, 2007.

Salgado, R. M.; Favaro, R. R.; Martin, S. S. \& Zorn, T. M. The estrous cycle modulates small leucine-rich proteoglycans expression in mouse uterine tissues. Anat. Rec., 292(1):138-53, 2009a.

Salgado, R. M.; Capelo, L. P.; Favaro, R. R.; Glazier, J. D.; Aplin, J. D.; Zorn, T. M. Hormone-regulated expression and distribution of versican in mouse uterine tissues. Reprod. Biol. Endocrinol., 7:60, 2009b.

San Martin, S.; Soto-Suazo, M. \& Zorn, T. M. Distribution of versican and hyaluronan in the mouse uterus during decidualization. Braz. J. Med. Biol. Res., 36(8):1067$71,2003$.

Santos, A. R. Jr.; Dolder, H. \& Wada, M. L. F. Effects of fetal calf serum and dexamethasone in the differentiation of fibroblastic cells cultured on collagen I gel. $J$. Submicrosc. Cytol. Pathol., 35(1):35-42, 2003.

Staun-Ram, E. \& Shalev, E. Human trophoblast function during the implantation process. Reprod. Biol. Endocrinol., 3:56-68, 2005.

Taboga, S. R. \& Vilamaior, P. S. L. Métodos de estudo da célula. Citoquímica. In: A célula (Carvalho, H.F. \& Recco-Pimentel, S.M. eds.). $2^{\text {a }}$ ed., Manole, Barueri, 2007. pp.42-50.

\section{Correspondence to:}

Arnaldo Rodrigues Santos Jr.

Centro de Ciências Naturais e Humanas

Universidade Federal do ABC

Avenida dos Estados,

Santo André, SP

5001, Bangu

Santo André, 09210-971, SP,

BRASIL

Phone: 55.11.4996.0178

E-mail: arnaldo.santos@ufabc.edu.br 